\title{
NIR Bioluminescence Probe Enables Discovery of Diet-Induced Mod- ulation of the Tumor Microenvironment via Nitric Oxide
}

\author{
Anuj K. Yadav, Michael C. Lee, Melissa Y. Lucero, Christopher J. Reinhardt, ${ }^{\dagger}$ Shengzhang Su, Jefferson \\ Chan* \\ Department of Chemistry and Beckman Institute for Advanced Science and Technology, University of \\ Illinois at Urbana-Champaign, Urbana, Illinois 61801, United States
}

KEYWORDS (Word Style "BG_Keywords"). If you are submitting your paper to a journal that requires keywords, provide significant keywords to aid the reader in literature retrieval.

\begin{abstract}
Nitric oxide (NO) plays a critical role in acute and chronic inflammation. NO's contributions to cancer are of particular interest due to its context-dependent bioactivities. For example, immune cells initially produce cytotoxic quantities of NO in response to the nascent tumor. However, it is believed that this fades over time and reaches a concentration that supports the tumor microenvironment (TME). These complex dynamics are further complicated by other factors, such as diet and oxygenation, making it challenging to establish a complete picture of NO's impact on tumor progression. Although many activity-based sensing (ABS) probes for NO have been developed, only a small fraction have been employed in vivo and fewer yet are practical in cancer models where the NO concentration is $<200 \mathrm{nM}$. To overcome this outstanding challenge, we have developed BL $660-\mathrm{NO}$, the first ABS probe for NIR bioluminescence imaging of NO in cancer. Owing to the low intrinsic background, high sensitivity, and deep tissue imaging capabilities of our design, BL $660-\mathrm{NO}$ was successfully employed to visualize endogenous NO in cellular systems, a human liver metastasis model, and a murine breast cancer model. Importantly, its exceptional performance facilitated the design of a dietary study to examine the impact of $\mathrm{NO}$ on the TME by varying the intake of fat. BL 660 -NO provides the first direct molecular evidence that intratumoral NO becomes elevated in mice fed a high-fat diet who became obese with larger tumors compared to control animals on a low-fat diet. These results indicate that an inflammatory diet can increase NO production via recruitment of macrophages and overexpression of iNOS which in turn can drive tumor progression.
\end{abstract}

\section{Introduction}

Nitric oxide (NO) is a radical species that has been implicated in vasodilation, ${ }^{1}$ neuronal signaling, ${ }^{2}$ immunology ${ }^{3,4}$ and cancer. $^{5}$ These diverse physiological and pathological roles warrant the development of tools for in vivo detection. This is especially true in the context of cancer, in which NO functions in various, sometimes contradictory, signaling pathways within the tumor microenvironment (TME). ${ }^{6}$ For example, high expression of nitric oxide synthase in activated macrophage exert cytostatic or cytotoxic effects. On the other hand, resident macrophage within the TME (i.e., tumor-associated macrophage) tend to produce low steady-state concentrations of $\mathrm{NO}(<200 \mathrm{nM})$ and are associated with a more aggressive phenotype, as well as poorer clinical prognosis. ${ }^{7,8}$ These concentration-dependent effects suggest that other factors that modulate inflammation, such as diet, may be important in the context of cancer prevention and/or treatment. ${ }^{9-13}$

In vivo molecular imaging is an attractive approach to examine the contributions of inflammation in driving cancer. This extends beyond traditional means, such as measuring inducible nitric oxide synthase (iNOS) expression levels or the extent of macrophage infiltration via immunohistostaining, to provide a direct, real-time link between NO production and cancer within live animals. NO's fleeting nature remains a limiting challenge in terms of live animal imaging. ${ }^{6}$ Current techniques for directly monitoring NO in vivo have proven useful, but have drawbacks, such as low resolution (EPR), ${ }^{14,15}$ poor sensitivity (MRI), ${ }^{16,17}$ or invasiveness (amperometry). ${ }^{18} \mathrm{~A}$ complementary approach is the use of activity-based sensing (ABS) probes ${ }^{19,20}$ which exploit the chemical reactivity of the target analyte to report on activity with high selectivity. ${ }^{21-24}$ Until recently, most ABS probes for NO have been developed for fluorescence imaging in cellular systems. ${ }^{25}$ In contrast, their use in vivo is restricted by significant scattering of light. The transition to longer excitation and emission wavelengths (visible to NIR) reduces these effects and has facilitated several successful studies in live animals; however, most of these examples were in lipopolysaccharide (LPS) models where the concentration of NO is $10^{3}$-fold higher than in those found in cancer. ${ }^{26}$ Our group, as well as others, have been interested in addressing these limitations in terms of both depth penetration and sensitivity. Along these lines, we developed the first ABS probe for photoacoustic imaging of NO and applied it to an LPS-induced murine inflammation model. ${ }^{27}$ Since our work, different strategies have been reported and validated in similar inflammatory models. ${ }^{28,29} \mathrm{By}$ rationally tuning our first-generation probe, we have designed light-activatable NO donors, ${ }^{30,31}$ as well as new photoacoustic probes that exhibit an improved limit of detection which has allowed us to visualize endogenous NO in a murine model of breast cancer. ${ }^{32}$ 
Unlike fluorescence imaging (light-in, light-out) and photoacoustic imaging (light-in, sound-out), bioluminescence (BL) imaging does not rely on external light excitation to generate a readout. ${ }^{33,34}$ As such, BL imaging offers improved sensitivity by circumventing incident light, as well as decreased background that results from autofluorescence or endogenous chromophores that are photoacoustic-active. ${ }^{35}$ Although numerous ABS probes for BL imaging have been developed, ${ }^{36-47}$ deep tissue imaging of NO in the TME has remained elusive. BioLeT is a notable $\mathrm{BL}$ probe that was employed for the detection of exogenous NO (delivered in the form of a NO donor) in vivo. ${ }^{48}$ BioLeT is based on an amino-luciferin scaffold which emits visible light and therefore is best-suited for imaging at shallow depths. Recently, the development of near infrared (NIR) BL technologies such as red-shifted substrates ${ }^{49-52}$ and optimized luciferase enzymes ${ }^{53-55}$ have presented exciting opportunities for deeper tissue imaging. Despite these advances, no ABS probes, for any analyte, exist for NIR BL imaging.

Herein, we report the development of BL $660-\mathrm{NO}$ : the first ABS probe for NIR BL detection of NO in cancer. $\mathrm{BL}_{660}-\mathrm{NO}$ was successfully applied for imaging in live cells, and murine models of liver and breast cancer. Moreover, we employed BL $660-$ NO to investigate the effect of diet on the TME, in which a highfat diet resulted in increased NO production as compared to mice fed a low-fat diet. This work highlights the importance of studying the influence of pro-inflammatory stimuli in the context of cancer prevention, treatment, and progression.

\section{Results and Discussion}

\section{Design and Synthesis of BL660-NO}

$\mathrm{BL}_{660}-\mathrm{NO}$ was designed to satisfy the following criteria to maximize in vivo performance. First, the emission maxima should be in the NIR range $(>650 \mathrm{~nm})$ to enable deep tissue imaging where scattering and attenuation of emitted light is limited. Second, the substrate should turnover rapidly in the presence of wildtype firefly luciferase (herein referred to as luciferase) to leverage established cell lines and animal models. Third, the design should be synthetically assessable, modular, and easy to diversify. With these considerations in mind, we selected AkaLumine $^{49}$ as the starting point. By exchanging the $N, N$-dimethyl group with other $N, N$-dialkyl moieties, the lipophilic character of the resulting substrates can be tuned to maximize tumor accumulation. ${ }^{56}$ We found the $N, N$-diethyl modification $\left(\mathrm{BL}_{660}\right)$ was ideal since in addition to meeting the three criteria above, it was highly stable in cell culture media for up to $12 \mathrm{~h}$ (Figure S1). We hypothesized that capping the carboxylate group with an NO-responsive unit (e.g., o-phenylenediamine trigger $)^{57}$ would prevent enzymatic activity with luciferase. However, the reaction with $\mathrm{NO}$ (via the active species $\mathrm{N}_{2} \mathrm{O}_{3}$ ) is expected to be rapid en route to generate an acyl triazole intermediate, which can undergo spontaneous rate-limiting hydrolysis to yield $\mathrm{BL}_{660}$. The resulting substrate can then react with luciferase $\left(K_{\mathrm{m}}=5.54 \pm 0.95\right)$ to generate BL in the NIR range $\left(\lambda_{\mathrm{em}}=660 \mathrm{~nm}\right)$ (Figures 1a and S2). This is critical since it means our probe is compatible with any luciferase expressing cell line. An added benefit of this design strategy is that it masks the negative charge and should facilitate rapid uptake, as opposed to substrates such as luciferin.
The synthesis ${ }^{49,58}$ of $\mathrm{BL}_{660} \mathrm{-NO}$ began with the HornerWadsworth-Emmons olefination reaction between 4-diethylaminobenzaldehyde and triethyl 4-phosphonocrotonate to afford the conjugated trans-diene ester 1 in 53\% yield. Hydrolysis of the ester to the corresponding carboxylic acid proceeded quantitatively in acetonitrile-water to yield acid 2. Condensation of 2 with $S$-trityl protected D-cysteine methyl ester, followed by cyclization in the presence of trifluoromethanesulfonic anhydride and triphenylphosphine oxide furnished the thiazoline methyl ester intermediate 3 in $82 \%$ yield. Hydrolysis of the methyl ester group with Pig liver esterase afforded the free acid 4 (BL $\left.{ }_{660}\right)$ in $43 \%$ yield. Finally, 4 was coupled to $o$-phenylenediamine using HBTU to afford the final probe, $\mathrm{BL}_{660}-\mathrm{NO}$, in $33 \%$ yield (Figure 1b). We also prepared a non-responsive control compound (Ctrl-BL $66_{60} \mathrm{NO}$ ) to confirm the proposed NO- and luciferase-dependent activation. Ctrl-BL $660-\mathrm{NO}$ was synthesized using the same reaction sequence above; however, we employed $m$-phenylenediamine, instead of the $o$-phenylenediamine trigger, because it cannot form the labile acyl triazole intermediate necessary to generate $\mathrm{BL}_{660}$ (Figure S3).
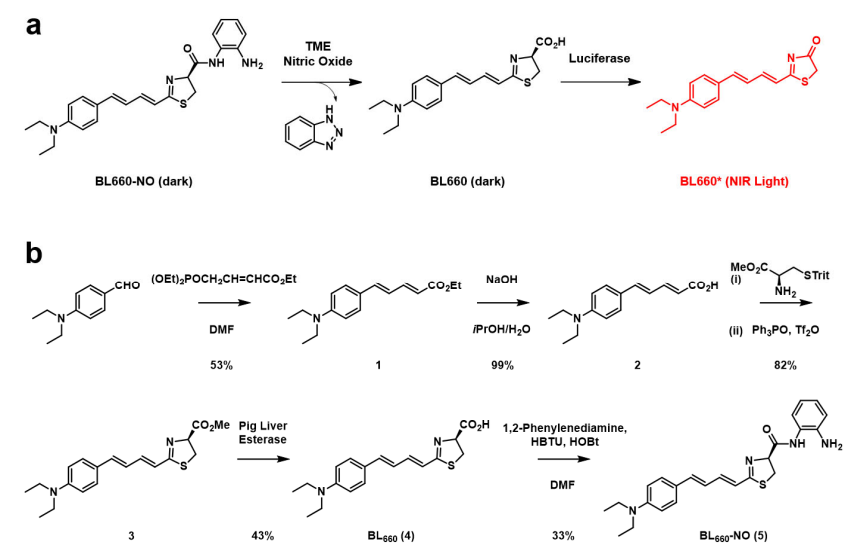

Figure 1. a) Schematic representation of $\mathrm{BL}_{660} \mathrm{NO}$ reaction with NO and wild type luciferase to produce a NIR bioluminescent signal. b) Synthesis of BL $660-N O$.

\section{In Vitro Characterization}

With $\mathrm{BL}_{660}$ and $\mathrm{BL}_{660} \mathrm{-NO}$ in hand, we first obtained a bioluminescent spectrum of $\mathrm{BL}_{660}$ to reveal that the emission maximum is separated from the corresponding maximum of luciferin $\left(\lambda_{\mathrm{em}}\right.$ $=560 \mathrm{~nm}$ ) by $100 \mathrm{~nm}$ (Figure 2a). Next, we examined the response of $\mathrm{BL}_{660}-\mathrm{NO}$ to $\mathrm{NO}$ and recombinant luciferase in vitro by incubating the probe with an NO donor (DEA NONOate $250 \mu \mathrm{M}$ ) for $30 \mathrm{~min}\left(\mathrm{pH} 8\right.$ and $\left.37^{\circ} \mathrm{C}\right)$. The reaction mixture was then treated with ATP-MgSO 4 and luciferase $(0.05 \mathrm{mg} / \mathrm{mL})$. We confirmed via LCMS analysis that BL660 and the benzotriazole by-product was being generated, consistent with the proposed activation mechanism (Figure S4). We further demonstrated that both NO and luciferase were essential to generate a BL signal (Figure 2b). Linear relationships were observed between the BL signal and either probe or NO concentration while holding the other parameter constant (Figure 2c-d). Next, we tested the selectivity of BL ${ }_{660}-\mathrm{NO}$ by incubating it with various biologically relevant analytes in the presence of luciferase. For instance, we evaluated its reactivity with several reactive carbonyl species (i.e., formaldehyde, glyoxal, acetaldehyde, dehydroascorbic acid) which can generate various cyclized 
products. ${ }^{59-61}$ Moreover, we tested a panel of reactive oxygen species (i.e., hydrogen peroxide, tert-butyl hydrogen peroxide, hypochlorite, superoxide anion, hydroxyl radical) and reactive nitrogen species (i.e., nitrite, nitrate, nitroxyl, peroxynitrite) that could react with the substrate component or the trigger to give undesirable activation. Negligible changes $(<6 \%)$ in the bioluminescent signal were observed with up to 75 -fold molar excess of each species, indicating exceptional selectivity (Figure 2e). In contrast, treatment of BL660-NO with $\mathrm{NO}$ resulted in a robust signal enhancement.
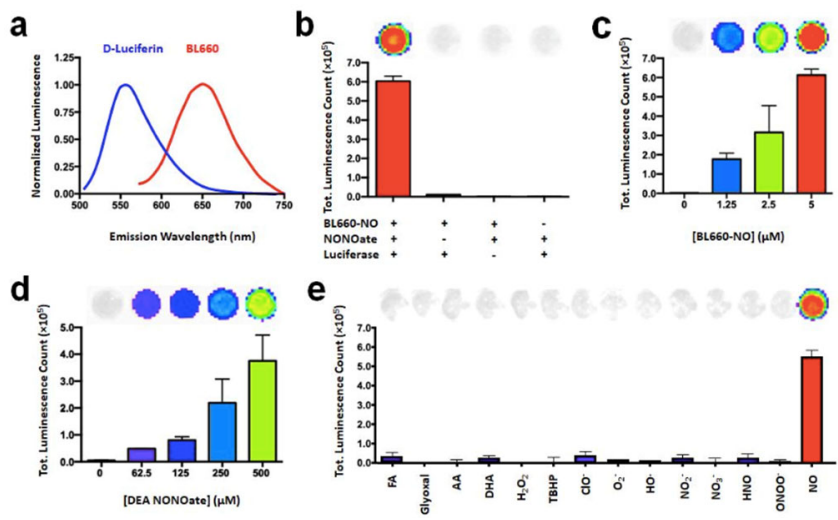

Figure 2. a) Spectra of luciferin and BL660 in presence of recombinant luciferase. b) In vitro assay demonstrating probe, $\mathrm{NO}$, and luciferase must all be present to generate a signal. BL660-NO $(5 \mu \mathrm{M})$, DEA NONOate $(250 \mu \mathrm{M})$, luciferase $(0.05 \mathrm{mg} / \mathrm{mL})$. c) Bioluminescent signal as a function of $\mathrm{BL}_{660} \mathrm{NO}$ concentration $(0,1.25$, $2.5,5 \mu \mathrm{M})$. d) Bioluminescent signal as a function of DEA NONOate concentration $(0,62.5,125,250,500 \mu \mathrm{M})$. e) Selectivity assay against a panel of biologically relevant analytes. All analytes were present in 75 -fold excess relative to $\mathrm{BL}_{660} \mathrm{NO}(5 \mu \mathrm{M})$. All data is reported as the mean \pm standard deviation $(n=3)$.

\section{Detection of NO in Cancer Cells with BL660-NO}

Next, we evaluated the responsiveness of BL660-NO toward endogenous NO in human A549-Luc2 lung cancer cells and murine 4T1-Luc breast cancer cells. Of note, the detection of basal levels of NO in cell culture is challenging owing to the absence of external stimulus (e.g., TME) that can induce the overexpression of iNOS and subsequent overproduction of NO. Cells were treated with $10 \mu \mathrm{M} \mathrm{BL}_{660}-\mathrm{NO}$ and imaged immediately. Within few minutes, the cells became highly bioluminescent compared to vehicle controls (Figure 3a-d). To determine if this turn-on response was due to NO, we pretreated cells with L-NMMA, a non-selective inhibitor of human and murine NOS, before application of $\mathrm{BL}_{660}-\mathrm{NO} .^{62} \mathrm{We}$ observed a statistically significant decrease in the bioluminescent signal for both cell lines under these conditions (Figure 3a-d). These results are important because they indicate BL $660-\mathrm{NO}$ exhibits exceptional sensitivity necessary to detect $\mathrm{NO}$ at basal levels, even within cell cultures. Before applying BL660-NO in vivo, we performed standard MTT assays to assess its potential cytotoxicity. Cells were incubated with $\mathrm{BL}_{660}-\mathrm{NO}$ at various concentrations $(0$ to $20 \mu \mathrm{M})$ for up to $3 \mathrm{~h}$. Even at the highest concentration of probe, we did not observe significant loss of cell viability (Figure S5), indicating $\mathrm{BL}_{660}-\mathrm{NO}$ would be suitable for in vivo applications.
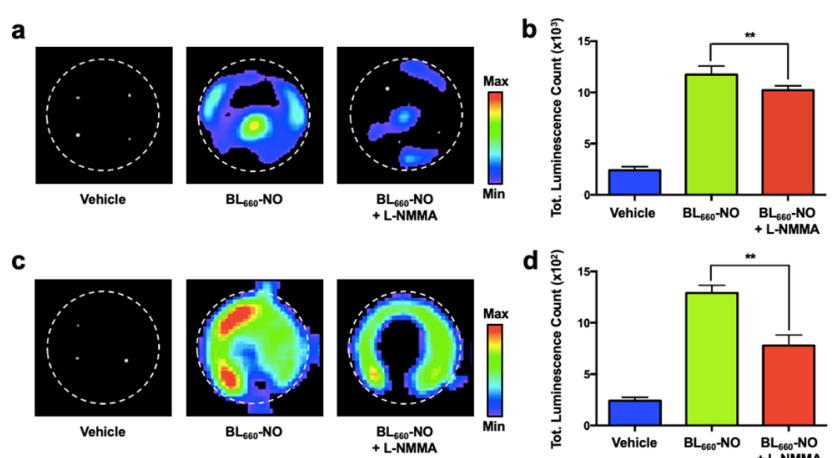

Figure 3. a) Representative images of BL signals from A549-Luc2 cells upon treatment with vehicle (DMSO), BL $660-\mathrm{NO}(10 \mu \mathrm{M})$ and pre-treatment with inhibitor L-NMMA (1 mM) for 30 min followed by BL $660-\mathrm{NO}(10 \mu \mathrm{M})$. b) Quantified data from a). c) Representative images of BL signals from 4T1-Luc upon treatment with vehicle (DMSO), BL660-NO $(10 \mu \mathrm{M})$ and pretreated with inhibitor LNMMA $(1 \mathrm{mM})$ for $30 \mathrm{~min}$ followed by BL660-NO $(10 \mu \mathrm{M})$. d) Quantified data from c). All data is reported as the mean \pm standard deviation $(n=3)$. Statistical analysis was performed using Student's t-test, $* *: \mathrm{p}<0.01$.

\section{Evaluation of BL660-NO in Liver and Breast Cancer Models}

First, we inoculated $\mathrm{Nu} / \mathrm{J}$ mice with A549-Luc2 cells using the intrahepatic procedure to generate heterotopic lung tumors. This experiment served to answer two questions: 1) does BL $660^{-}$ $\mathrm{NO}$ retain sufficient sensitivity to image basal, endogenous NO within live mice and 2) does this sensitivity extend into deep tissue (i.e., beyond the subcutaneous space). After eleven weeks, mice were treated with $\mathrm{BL}_{660}-\mathrm{NO}$ and imaged using the IVIS imaging system. The BL signals from the liver was $161 \pm$ 124-fold higher in tumor bearing mice than non-tumor controls confirming that $\mathrm{BL}_{660} \mathrm{-NO}$ can detect endogenous NO in deeptissue, heterotopic lung tumors. Although this study allowed us to evaluate our probe in a human cancer cell line, it is important to note that nude mice lack a functional immune system which is critical for establishing the TME. For this reason, subsequent experiments were performed in syngeneic murine models. a

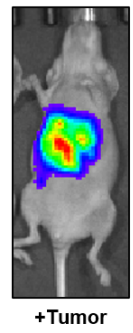

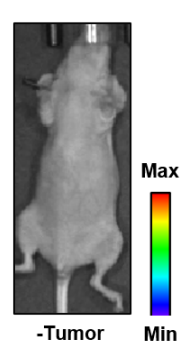

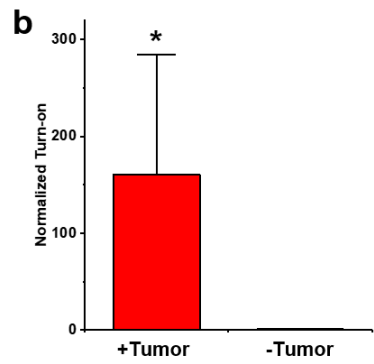

Figure 4. a) Representative BL images of A549-Luc2 tumor bearing $(n=6)$ and non-tumor bearing $(n=4)$ mice treated with BL660NO. b) Normalized data from a). All data was reported as the mean \pm standard deviation. Statistical analysis was performed using an unpaired t-test, $*$ : $\mathrm{p}<0.05$.

In particular, we established a heterotopic 4T1-Luc breast cancer allograft model in BALB/c mice via subcutaneous injection in the flank. The tumors were allowed to grow to $300-400 \mathrm{~mm}^{3}$ ( $\sim 30$ days). BL $660-\mathrm{NO}$ was then administered systemically, and the BL signal was monitored. We observed a signal enhancement in the tumor region that persisted for at least two hours. 
To verify that this was due to NO, we divided the tumor-bearing mice into two groups which were treated with a vehicle control (saline) or L-NMMA prior to administration of $\mathrm{BL}_{660}-\mathrm{NO}$. We hypothesized that the NOS inhibitor would attenuate the BL signal if NOS-derived NO was responsible for the probe activation. We observed a turn-on response of $2.2 \pm 0.3$ (defined as the ratio of the $\mathrm{BL}$ signal at $1 \mathrm{~h}$ relative to immediately after BL $660-\mathrm{NO}$ treatment) in the vehicle group. In comparison, we did not note any change in signal intensity of the L-NMMA treatment group. To further corroborate our results, we introduced Ctrl-BL660-NO, a non-responsive isomer of our probe, via intratumoral injection. We selected this route of administration as opposed to systemic injection to account for possible differences in biodistribution and uptake into the tumors. As anticipated, we did not observe any signal enhancement relative to $\mathrm{BL}_{660}$-NO (Figure S6).

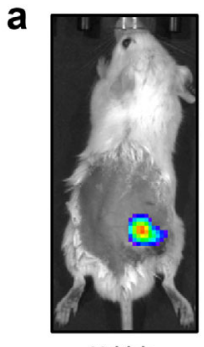

Vehicle

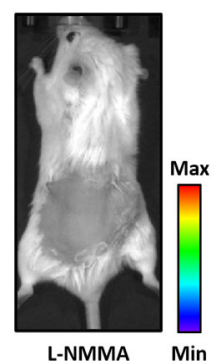

L-NMMA Min

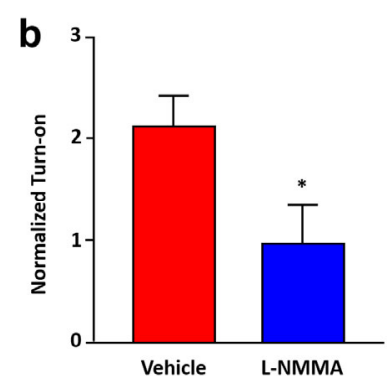

Figure 5. a) Representative BL images of mice pre-treated with a vehicle control (saline) or L-NMMA (35 mM, $50 \mu \mathrm{L})$. b) Normalized data from a). All data is reported as the mean \pm standard deviation $(n=3)$. Statistical analysis was performed using Student's ttest, $*$ : $\mathrm{p}<0.05$.

\section{Effect of Diet on NO Generation in Heterotopic Breast Can- cer Model with BL ${ }_{660}-\mathrm{NO}$}

Numerous studies have suggested that high-fat diets are a risk factor for breast cancer because they promote chronic inflammatory states ${ }^{12,63-68}$ For instance, a recent study of 337,000 women found those who ate the most saturated fat were approximately $30 \%$ more likely to develop breast cancer compared to their counterparts who ate the lowest levels. ${ }^{69}$ However, relating these findings to a molecular entity such as NO has not been possible to date. With the development of $\mathrm{BL}_{660}-\mathrm{NO}$, we sought to design an experiment to determine the impact of a high-fat diet on inflammation, NO generation in the TME, and tumorigenesis. Specifically, we elected to employ an orthotopic breast cancer model since this would allow us to study the effects of diet in the native TME. First, we randomly divided female BALB/c mice into two groups to be fed low-fat and high-fat diets, in which $10 \%$ and $60 \%$ of calories are from fat, respectively, for 12 weeks. Of note, we did not control their caloric intake by allowing the mice to feed freely to mimic the variable food consumption behavior of humans. After this period, 4T1Luc cells were injected into the mammary fat pads and the same diets were continued until the end of the study (Figure 6a). Consistent with previous reports, the mice in the high-fat group became obese and were $60 \%$ heavier (37.3 g vs. $23.3 \mathrm{~g}$ ). Moreover, the tumor volume of the low-fat and high-fat diet groups were measured to be $176.7 \pm 41.5 \mathrm{~mm}^{3}$ and $223.9 \pm 74.3 \mathrm{~mm}^{3}$, respectively. This raises an important consideration, that is, since the tendency for high-fat animals is to have larger tumors on average, would the presence of more luciferase expressing cancer cells give confounding results since it would be difficult to determine if a higher BL signal is due to more NO or more luciferase.

To distinguish this, we designed a cell-based study where we performed ratiometric BL imaging with $\mathrm{BL}_{660} \mathrm{NO}$ and luciferin. We hypothesized that the ratio between luciferin emission and BL $660-\mathrm{NO}$ emission (560/660) would be constant at a given NO concentration and it should not depend on the number of cells present if sensing of NO is rate-limiting. In contrast, if the number of cancer cells effects the 560/660 ratio, this would indicate $\mathrm{BL}_{660} \mathrm{NO}$ was reporting on luciferase levels instead of $\mathrm{NO}$ and thus, may be ineffective when tumor sizes differ. We tested this by treating one, two, or three million 4T1-Luc cells $/ \mathrm{mL}$ with either $62.5,125$, and $250 \mu \mathrm{M}$ DEA NONOate. The cells were then incubated with $\mathrm{BL}_{660}-\mathrm{NO}$ and imaged using the $660 \mathrm{~nm}$ filter set on the IVIS imaging system. Likewise, a second set of cells were treated with luciferin and imaged using the $560 \mathrm{~nm}$ filter set. We found the 560/660 ratio did not change as a function of cell number (Figure S7a). However, as the DEA NONOate concentration increased from 62.5 to 125 to $250 \mu \mathrm{M}$, the mean 560/660 ratio (obtained by averaging the ratio at different cell numbers) decreased in a concentration-dependant manner (Figure S7b). These results are consistent with NO detection being rate-limiting, which is an important feature of our probe design.

a

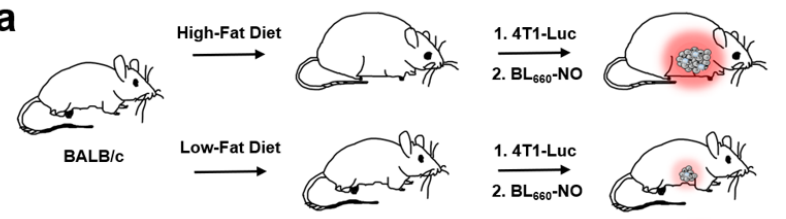

b
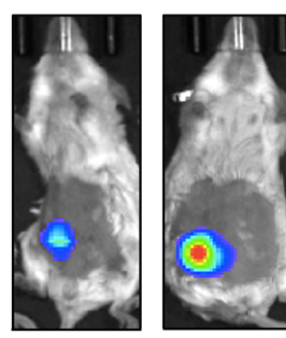

C

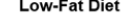

High-Fat Diet
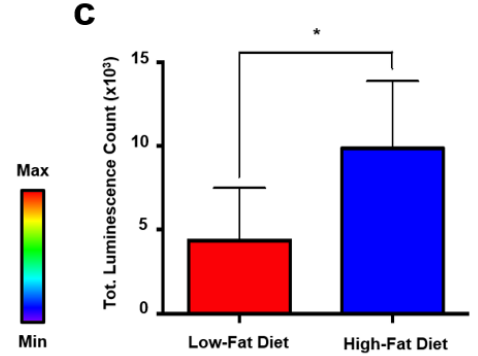

d
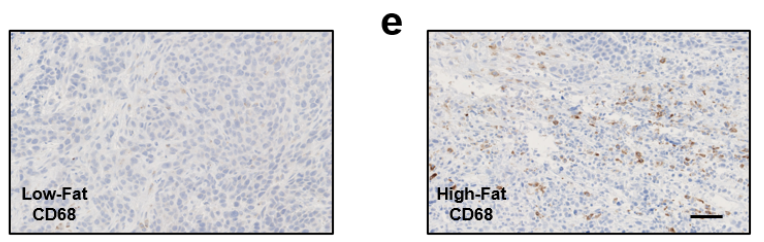

$\mathbf{f}$

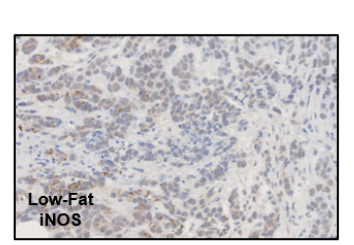

9

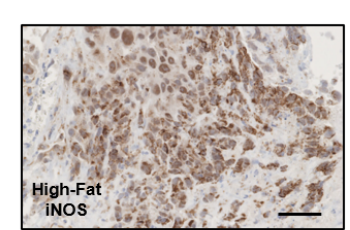

Figure 6. a) Schematic representing workflow for the generation of mouse models to study the effect of diet on tumorigenesis and NO production by bioluminescence imaging. b) Representative BL images of mice on low-fat and high-fat diets, respectively upon treatment with BL660-NO. c) Quantified data from b). All data is reported as the mean \pm standard deviation $(n=6)$. Statistical 
analysis was performed using Welch's t-test, $*$ : $\mathrm{p}<0.05$. Representative images of tumors excised from mice fed a d) low-fat diet and e) high-fat diet mice with CD68 staining. Scalebar $=50 \mu \mathrm{m}$. Representative images of tumors excised from mice fed a f) lowfat diet and g) high-fat diet mice with iNOS staining. Scalebar $=50$ $\mu \mathrm{m}$.

With these results, we proceeded to image NO with $\mathrm{BL}_{660}-\mathrm{NO}$. We found the BL signal was on average 2.63-fold higher in mice fed the high-fat diet than those fed the low-fat diet. Animals were sacrificed after imaging to harvest their tumors for further analysis. Tumors were subjected to immunohistochemical analyses of CD68, a protein overexpressed in circulating macrophages and tissue macrophages. We observed $38.5 \pm 9.9$ $\%$ of cells stained positive for CD68 in the tumors of the highfat mice, whereas only $2.9 \pm 0.6 \%$ of cells stained positive in the low-fat tumors (Figures 6d-e and S8). These results indicate a high-fat diet is correlated with increased macrophage infiltration. Likewise, we noted a significantly greater iNOS staining in the tumors $(77.9 \pm 9.3 \%$ vs $34.3 \pm 15.1 \%)$ of mice from the high-fat diet condition (Figures 6f-g and S9). Together, these results suggest that the consumption of a high-fat diet over a 12 week period promotes an inflammatory response within the TME that is linked to an increase in the number of tumor-associated macrophage and the overexpression of iNOS, which in turn are responsible for the elevated levels of NO that was detected by BL660-NO.

\section{Conclusion}

The detection of fleeting biological species such as NO using ABS probes in vivo is an immense challenge. For instance, in the context of cancer, NO levels have been reported to be less than $200 \mathrm{nM}$. We hypothesized we could detect subtle differences in endogenous NO levels by leveraging the low intrinsic background of BL, as well as reduced scattering and attenuation of emitted light in the NIR range. Although it is noteworthy that one example exists where the emission tail of the probe $\left(\lambda_{\mathrm{em}}=\right.$ $599 \mathrm{~nm}$ ) could be employed to detect fatty acid amide hydrolase activity via NIR BL imaging, ${ }^{47,51}$ BL $660-\mathrm{NO}$, is the first ABS probe where the $\lambda_{\mathrm{em}}$ is NIR. Upon evaluation, we found BL660NO to be selective, biocompatible, and highly sensitive as we could visualize basal levels of NO in systems ranging from cell cultures to numerous animal models.

Unlike fluorescence, photoacoustic, or chemiluminescence imaging, the generation of a bioluminescent readout requires the presence of luciferase. ${ }^{34,70}$ In a typical BL imaging experiment, a higher signal indicates there are more cells, and this is commonly used to track tumor progression. However, in the case of analyte sensing, the dependence on luciferase activity can confound results. Therefore, it could be difficult to discern whether a higher BL signal is due to more NO or more luciferase. To resolve this, we established a protocol where we would record the signal of BL660-NO and luciferin to calculate a ratio. Because NO sensing is rate-limiting, the ratio remains the same at a given NO concentration regardless of the number of cells. These results have important implications for the development of other BL probes.

Lastly, using $\mathrm{BL}_{660}-\mathrm{NO}$ in an orthotopic model of breast cancer we were able to study the impact of a high-fat diet on the TME. Although it has long been thought that a high-fat diet can promote tumor progression by creating an abnormal inflammatory
TME, ${ }^{71,72}$ the link to NO generation has been elusive owing to a dearth of real-time detection strategies of $\mathrm{NO}$ in vivo. Our data indicates that a high-fat diet can lead to greater macrophage infiltration of the TME, which in turn generates more NO via overexpression of iNOS. Understanding this relationship at the molecular level can help us better combat cancer by devising strategies to reduce an inflammatory response in the TME (e.g., by developing diets with low fat for cancer prevention). Moreover, with BL660-NO in hand, it is now possible to evaluate the efficacy of anti-inflammatory drugs or NO scavengers using any luciferase expressing cell line or animal model.

\section{Experimental Details}

\section{Synthetic Methods.}

Ethyl (2E,4E)-5-(4-(diethylamino)phenyl)penta-2,4-dienoate (1). Triethyl 4-phosphonocrotonate ( $1.8 \mathrm{ml}, 7.99 \mathrm{mmol}, 1.5$ equiv.) was added to a suspension of $\mathrm{NaH}(0.43 \mathrm{~g}, 10.65 \mathrm{mmol}, 2$ equiv.) in anhydrous THF $(10 \mathrm{ml})$ at $0{ }^{\circ} \mathrm{C}$. The reaction was stirred at this temperature for $20 \mathrm{~min}$ to give an orange colored mixture. A solution of 4-(diethylamino)benzaldehyde ( $0.94 \mathrm{~g}, 5.32 \mathrm{mmol}, 1$ equiv.) in anhydrous THF $(4.7 \mathrm{~mL})$ was added dropwise over $5 \mathrm{~min}$ and it was brought to room temperature and stirred for an additional $3 \mathrm{~h}$. The reaction was quenched with water and extracted with EtOAc $(3 \times)$. The combined organic layers were washed with brine, dried over $\mathrm{Na}_{2} \mathrm{SO}_{4}$, filtered, concentrated and purified via silica gel column chromatography (eluent: 4\% EtOAc in Hexanes) to afford 1 as a light yellow solid $(0.77 \mathrm{~g}, 2.82 \mathrm{mmol}, 53 \%$ yield $) .{ }^{1} \mathrm{H}$ NMR $\left(500 \mathrm{MHz}, \mathrm{CDCl}_{3}\right) \delta 7.44$ (dd, $\left.J=15.1,11.1 \mathrm{~Hz}, 1 \mathrm{H}\right), 7.33(\mathrm{~d}, J=$ $8.9 \mathrm{~Hz}, 2 \mathrm{H}), 6.81(\mathrm{~d}, J=15.4 \mathrm{~Hz}, 1 \mathrm{H}), 6.71-6.58(\mathrm{~m}, 3 \mathrm{H}), 5.86$ $(\mathrm{d}, J=15.2 \mathrm{~Hz}, 1 \mathrm{H}), 4.21(\mathrm{q}, J=7.1 \mathrm{~Hz}, 2 \mathrm{H}), 3.38(\mathrm{q}, J=7.1 \mathrm{~Hz}$, $4 \mathrm{H}), 1.31(\mathrm{~d}, J=14.3 \mathrm{~Hz}, 3 \mathrm{H}), 1.18(\mathrm{t}, J=7.1 \mathrm{~Hz}, 6 \mathrm{H}) .{ }^{13} \mathrm{C}$ NMR $\left(125 \mathrm{MHz}, \mathrm{CDCl}_{3}\right) \delta 167.74,148.52,146.08,141.42,129.07$, $123.32,121.28,117.88,111.51,60.14,44.55$.

(2E,4E)-5-(4-(diethylamino)phenyl)penta-2,4-dienoic acid (2). A 1 $\mathrm{M}$ solution of $\mathrm{NaOH}(2.75 \mathrm{~mL})$ was added to a suspension of 1 $(0.38 \mathrm{~g}, 1.39 \mathrm{mmol}, 1$ equiv. $)$ in isopropyl alcohol $(11 \mathrm{~mL})$ and refluxed for $8 \mathrm{~h}$. The reaction was then cooled to room temperature and the isopropyl alcohol was removed under vacuum. The mixture was acidified with a $1 \mathrm{M}$ solution of $\mathrm{HCl}$ and extracted with chloroform $(3 \times)$, washed with brine, dried over $\mathrm{Na}_{2} \mathrm{SO}_{4}$, filtered and concentrated to give 2 (0.34 g, $1.38 \mathrm{mmol}, 99 \%$ yield $).{ }^{1} \mathrm{H}$ NMR $\left(500 \mathrm{MHz}, \mathrm{CD}_{3} \mathrm{OD}\right) \delta 7.42(\mathrm{dd}, J=15.1,10.9 \mathrm{~Hz}, 1 \mathrm{H}), 7.36$ $(\mathrm{d}, J=8.9 \mathrm{~Hz}, 2 \mathrm{H}), 6.85(\mathrm{~d}, J=15.4 \mathrm{~Hz}, 1 \mathrm{H}), 6.75(\mathrm{dd}, J=15.4$, $10.9 \mathrm{~Hz}, 1 \mathrm{H}), 6.67$ (d, $J=9.0 \mathrm{~Hz}, 2 \mathrm{H}), 5.83(\mathrm{~d}, J=15.1 \mathrm{~Hz}, 1 \mathrm{H})$, $3.42(\mathrm{q}, J=7.1 \mathrm{~Hz}, 4 \mathrm{H}), 1.17(\mathrm{t}, J=7.1 \mathrm{~Hz}, 6 \mathrm{H}) .{ }^{13} \mathrm{C}$ NMR $(125$ $\left.\mathrm{MHz}, \mathrm{CD}_{3} \mathrm{OD}\right) \delta 171.30,149.94,148.19,143.12,130.11,124.68$, $122.03,118.44,112.65,45.37,12.92$.

Methyl (S)-2-((1E,3E)-4-(4-(diethylamino)phenyl)buta-1,3-dien-1yl)-4,5-dihydrothiazole-4-carboxylate (3). A solution of 2 (0.5 g, 2.04 mmol, 1 equiv.) and D-cysteine-( $S$-Trityl)-OMe (0.85 g, 2.25 mmol, 1.1 equiv.) in anhydrous DMF $(20.4 \mathrm{~mL})$ was treated with EDC (1.32 g, 6.88 mmol, 3.38 equiv.) and DMAP (0.64 g, 5.24 mmol, 2.56 equiv.). The reaction was stirred at room temperature under $\mathrm{N}_{2}$ for $24 \mathrm{~h}$, quenched water and extracted with EtOAc $(3 \times)$. The combined organic layers were dried over $\mathrm{Na}_{2} \mathrm{SO}_{4}$, filtered, concentrated and passed through a silica plug and used in the next reaction without further purification. In part 2 , a solution of triphenylphosphine oxide (1.12 g, $4.02 \mathrm{mmol}, 3$ equiv.) in anhydrous $\mathrm{CH}_{2} \mathrm{Cl}_{2}(14 \mathrm{~mL})$ was cooled to $0{ }^{\circ} \mathrm{C}$ under $\mathrm{N}_{2}$. $\mathrm{Tf}_{2} \mathrm{O}$ ( $0.34 \mathrm{~mL}, 2.02 \mathrm{mmol}, 1.5$ equiv.) was then slowly added dropwise and stirred for $30 \mathrm{~min}$. The intermediate prepared in part $1(0.81 \mathrm{~g}$, 1.34 mmol, 1 equiv.) was dissolved in anhydrous $\mathrm{CH}_{2} \mathrm{Cl}_{2}(13 \mathrm{~mL})$ and added dropwise at $0{ }^{\circ} \mathrm{C}$. The resulting reaction mixture was 
stirred for 10 min and quenched with saturated $\mathrm{NaHCO}_{3}$ and extracted with $\mathrm{CH}_{2} \mathrm{Cl}_{2}(3 \times)$. The combined organic layers were washed with brine, dried over $\mathrm{Na}_{2} \mathrm{SO}_{4}$, filtered, concentrated, and purified by silica gel column chromatography (eluent: 20\% EtOAc in Hexanes) to give $3(0.58 \mathrm{~g}, 1.68 \mathrm{mmol}, 82 \%$ yield $) .{ }^{1} \mathrm{H}$ NMR $\left(500 \mathrm{MHz}, \mathrm{CDCl}_{3}\right) \delta 7.33(\mathrm{~d}, J=8.5 \mathrm{~Hz}, 2 \mathrm{H}), 6.94(\mathrm{dd}, J=15.3$, $10.2 \mathrm{~Hz}, 1 \mathrm{H}), 6.78-6.65(\mathrm{~m}, 2 \mathrm{H}), 6.62(\mathrm{~d}, J=8.4 \mathrm{~Hz}, 2 \mathrm{H}), 6.52$ $(\mathrm{d}, J=15.3 \mathrm{~Hz}, 1 \mathrm{H}), 5.16(\mathrm{t}, J=9.0 \mathrm{~Hz}, 1 \mathrm{H}), 3.82(\mathrm{~s}, 3 \mathrm{H}), 3.62-$ $3.49(\mathrm{~m}, 2 \mathrm{H}), 3.38(\mathrm{q}, J=7.0 \mathrm{~Hz}, 4 \mathrm{H}), 1.18(\mathrm{t}, J=7.0 \mathrm{~Hz}, 6 \mathrm{H}) .{ }^{13} \mathrm{C}$ NMR $\left(125 \mathrm{MHz}, \mathrm{CDCl}_{3}\right) \delta 171.62,170.42,148.42,144.13,139.82$, 128.96, 123.54, 122.29, 122.12, 111.57, 52.93, 44.58, 34.68, 12.77 . HRMS $[\mathrm{M}+\mathrm{H}]^{+}$calculated mass for $\mathrm{C}_{19} \mathrm{H}_{25} \mathrm{~N}_{2} \mathrm{O}_{2} \mathrm{~S}=345.1637$, found $=345.1632$.

$B L_{660}$ (4). Pig liver esterase (76 mg) was added to a suspension of $3(0.2 \mathrm{~g}, 0.58 \mathrm{mmol}, 1$ equiv. $)$ in ethanol $(17 \mathrm{~mL})$ and $10 \mathrm{mM}$ $\mathrm{NH}_{4} \mathrm{HCO}_{3}(50 \mathrm{~mL})$ at $\mathrm{pH} 7.8$. The reaction was stirred at $37^{\circ} \mathrm{C}$ for $19 \mathrm{~h}$ under argon. The reaction mixture was concentrated and the residue was suspended in $1: 1 \mathrm{v} / \mathrm{v} \mathrm{MeOH} / \mathrm{CHCl}_{3}$. The precipitates were removed via filtration and washed. The filtrate was concentrated under vacuum to give $4(0.082 \mathrm{~g}, 0.248 \mathrm{mmol}, 43 \%$ yield). ${ }^{1} \mathrm{H}$ NMR $\left(500 \mathrm{MHz}, \mathrm{CD}_{3} \mathrm{OD}\right) \delta 7.37(\mathrm{~d}, J=8.9 \mathrm{~Hz}, 2 \mathrm{H})$, $7.13-7.05(\mathrm{~m}, 1 \mathrm{H}), 6.89-6.75(\mathrm{~m}, 2 \mathrm{H}), 6.68(\mathrm{~d}, J=8.9 \mathrm{~Hz}, 2 \mathrm{H})$, $6.50(\mathrm{~d}, J=15.1 \mathrm{~Hz}, 1 \mathrm{H}), 5.02(\mathrm{t}, J=8.7 \mathrm{~Hz}, 1 \mathrm{H}), 3.67-3.55(\mathrm{~m}$, 2H), 3.42 (q, $J=7.1 \mathrm{~Hz}, 4 \mathrm{H}), 1.17(\mathrm{t}, J=7.1 \mathrm{~Hz}, 6 \mathrm{H}) .{ }^{13} \mathrm{C} \mathrm{NMR}$ $\left(125 \mathrm{MHz}, \mathrm{CD}_{3} \mathrm{OD}\right) \delta 150.10,147.22,142.99,130.33,124.79$, $122.69,112.71,78.38,45.40,36.07,12.93$. HRMS $[\mathrm{M}+\mathrm{H}]^{+}$ calculated mass for $\mathrm{C}_{18} \mathrm{H}_{23} \mathrm{~N}_{2} \mathrm{O}_{2} \mathrm{~S}=331.1480$, found $=331.1475$.

$B L 660-N O$ (5). A solution of 4 (0.21 g, 0.64 mmol, 1 equiv.), 1,2phenylenediame ( $0.14 \mathrm{~g}, 1.29 \mathrm{mmol}, 2$ equiv.), HBTU ( $0.24 \mathrm{~g}, 0.64$ mmol, 1 equiv.) and $\mathrm{HOBt}(0,097 \mathrm{~g}, 0.63 \mathrm{mmol}, 1$ equiv.) in anhydrous DMF $(8.0 \mathrm{~mL})$ was stirred under $\mathrm{N}_{2}$ for 5 min. DIPEA ( $0.11 \mathrm{~mL}, 0.63 \mathrm{mmol}, 1$ equiv.) was added and the reaction mixture and stirred at room temperature overnight. The reaction was diluted with water and extracted with EtOAc $(3 \times)$. Combined organic layers were dried over $\mathrm{Na}_{2} \mathrm{SO}_{4}$, filtered, concentrated, and purified using silica gel column chromatography (eluent: $1 \% \mathrm{MeOH}$ in Dichloromethane) to afford $\mathrm{BL}_{660}-\mathrm{NO}$ as a dark red solid $(0.088 \mathrm{~g}$, $0.209 \mathrm{mmol}, 33 \%$ yield). ${ }^{1} \mathrm{H}$ NMR $\left(500 \mathrm{MHz}, \mathrm{CD}_{3} \mathrm{OD}\right) \delta 7.90(\mathrm{~s}$, 1H), 7.36 (d, $J=9.0 \mathrm{~Hz}, 2 \mathrm{H}), 7.22$ (dd, $J=7.9,1.5 \mathrm{~Hz}, 1 \mathrm{H}), 7.10$ $-7.00(\mathrm{~m}, 2 \mathrm{H}), 6.86(\mathrm{dd}, J=8.0,1.2 \mathrm{~Hz}, 1 \mathrm{H}), 6.80(\mathrm{~d}, J=8.8 \mathrm{~Hz}$, $1 \mathrm{H}), 6.76-6.59(\mathrm{~m}, 4 \mathrm{H}), 6.54(\mathrm{~d}, J=15.3 \mathrm{~Hz}, 1 \mathrm{H}), 5.25(\mathrm{t}, J=9.2$ $\mathrm{Hz}, 1 \mathrm{H}), 3.71-3.60(\mathrm{~m}, 2 \mathrm{H}), 3.42(\mathrm{q}, J=7.1 \mathrm{~Hz}, 4 \mathrm{H}), 1.17(\mathrm{t}, J=$ $7.0 \mathrm{~Hz}, 6 \mathrm{H}) .{ }^{13} \mathrm{C}$ NMR $\left(125 \mathrm{MHz}, \mathrm{CD}_{3} \mathrm{OD}\right) \delta 173.33,172.27$, $149.86,145.90,143.30,141.76,132.03,130.00,128.46,127.10$, $124.85,124.50,122.76,122.42,119.43,118.40,112.67,79.97$, 49.51, 45.36, 35.66, 12.93. HRMS $[\mathrm{M}+\mathrm{H}]^{+}$calculated mass for $\mathrm{C}_{24} \mathrm{H}_{29} \mathrm{~N}_{4} \mathrm{OS}=421.2062$, found $=421.2047$.

Analyte Selectivity Assay. The response of BL660-NO (5 $\mu \mathrm{M})$ toward a panel of biologically relevant aldehydes, reactive oxygen species and reactive nitrogen species (50 equiv.) in a 96-well culture plate was monitored using the IVIS imaging system. BL660-NO was incubated with each analyte at $37^{\circ} \mathrm{C}$ for $30 \mathrm{~min}$ before the reaction was initiated by adding ATP- $\mathrm{MgSO}_{4}$ and luciferase. Light was collected immediately after mixing, and the relative signal enhancement was determined relative to control wells not treated with analyte. The total volume of each well was $100 \mu \mathrm{L}(50 \mathrm{mM}$ Tris buffer $(\mathrm{pH} 8.0)$ with $0.5 \%$ DMSO). Formaldehyde solutions were prepared by depolymerizing saturated aqueous solutions at $100{ }^{\circ} \mathrm{C}$ before use. Dehydroascorbic acid was prepared by dissolving the solid at $65{ }^{\circ} \mathrm{C}$ in water before cooling to room temperature for use. Superoxide anion was added as a solution of potassium superoxide in DMSO. Nitroxyl was generated in situ from a solution of Angeli's salt in degassed $10 \mathrm{mM}$ potassium hydroxide solution. Peroxynitrite was prepared according to previously reported literature. NO was generated in situ from a solution of DEA-NONOate in degassed PBS buffer. All other analytes were prepared by dilution or dissolution from commercially available sources.

Cellular Imaging in A549-Luc2 and 4T1-Luc Cells with BL660-NO. 24-well culture plates were seeded with A549-Luc2 or $4 \mathrm{~T} 1$-Luc cells $(500 \mu \mathrm{L}$ of 250,000 cells $/ \mathrm{mL}$ per well) and incubated at $37{ }^{\circ} \mathrm{C}$ with $5 \% \mathrm{CO}_{2}$ for 24 hours. After this period, cells were $\sim 85 \%$ confluent. Cells were then treated with a 10 $\mu \mathrm{M}$ solution of $\mathrm{BL}_{660} \mathrm{NO}(0.5 \%$ DMSO final concentration) and imaged immediately using the IVIS imaging system with a $660 \mathrm{~nm}$ filter. To perform inhibition studies, we replaced the media with serum-free RPMI 1640 with or without L-NMMA (final concentration $1 \mathrm{mM}$ ). The cells were incubated for $30 \mathrm{~min}$ before BL $660-\mathrm{NO}$ was applied for BL imaging.

Application of BL $66_{0}-\mathrm{NO}$ and Luciferin for Ratiometric BL Imaging. 4T1-Luc cells were trypsinized, pelleted, and resuspended in serum-free RPMI 1640 media. The number of cells was determined using a Countess ${ }^{\mathrm{TM}}$ II Automated Cell Counter. $200 \mu \mathrm{L}$ of cells at a density of one, two, or three million cells $/ \mathrm{mL}$ were added to $0.6 \mathrm{~mL}$ Eppendorf tubes and incubated BL $660-\mathrm{NO}(10 \mu \mathrm{M})$ or a vehicle control (to account for the DMSO content used to solubilize $\mathrm{BL}_{660}-\mathrm{NO}$ ) for $15 \mathrm{~min}$ at $37{ }^{\circ} \mathrm{C}$. Luciferin $(0.47 \mathrm{mM})$ was then added to the tubes treated with the vehicle. DEA NONOate in degassed PBS was added to all tubes at a final concentration of $62.5,125$ or 250 $\mu \mathrm{M}$ and the tubes were incubated for an additional $30 \mathrm{~min}$ at 37 ${ }^{\circ} \mathrm{C}$. The tubes were then centrifuged for two min. The supernatant was discarded, and the cell pellet was resuspended in fresh serum-free RPMI 1640 media. The resuspended cells $(100 \mu \mathrm{L})$ was transferred to 96 -well culture plates and imaged using the IVIS imaging system using $560 \mathrm{~nm}$ filter set for luciferin treated cells and the $660 \mathrm{~nm}$ filter set for BL660-NO treated cells.

Formulation of BL660-NO for In Vivo Imaging. BL $660-\mathrm{NO}$ at $0.93 \mathrm{mg} / \mathrm{kg}$ was dissolved in a 1:4 solution of DMSO and sterile saline $(\mathrm{v} / \mathrm{v})$ and filtered through a $0.22 \mu \mathrm{m}$ sterile filter immediately prior to use.

Generation of A549-Luc2 Heterotopic Lung Cancer Model. Four to five-week old $\mathrm{Nu} / \mathrm{J}$ mice were used to surgically implant A549-Luc2 cancer cells into the liver. The mice were anesthetized, and aseptic technique was followed throughout the procedure. A laparotomy was performed to expose the liver. A cotton-tipped applicator was used to stabilize the lobe of the liver. The needle was inserted into the liver and slowly injected $5 \times 10^{6}$ cells $(50 \mu \mathrm{L}, 1: 1 \mathrm{PBS}$ :Matrigel). After injection, 5-0 Vicryl sutures were used to close the abdominal wall with 2 single interrupted sutures. Wound clips were used to close the skin, then removed after 10 days. Tumor growth was monitored for up to 11 weeks via bioluminescence imaging.

BL Imaging of Heterotopic Lung Cancer Model with BL 660 NO. Nude mice with and without A549-Luc2 tumors were treated with $\mathrm{BL}_{660}-\mathrm{NO}(0.93 \mathrm{mg} / \mathrm{kg}, 20 \% \mathrm{DMSO} / \mathrm{saline})$ via retro-orbital injection. After one hour, the mice were imaged on the IVIS imaging system. Light was collected using the open filter set. An ROI was drawn around the liver and the signal 
intensity was quantified using the Living Image Analysis Software. The counts were averaged and normalized to the nontumor bearing mice.

Generation of 4T1-Luc Breast Cancer Model. Female $\mathrm{BALB} / \mathrm{c}$ mice (six to eight weeks old) were inoculated with 4T1-Luc cells $\left(100 \mu \mathrm{L}\right.$ of $1 \times 10^{6}$ cells $/ \mathrm{mL}$ in $1: 1$ serum-free RPMI 1640 media and Matrigel) via subcutaneous injection into the flank. Tumor volumes were measured using the caliper method and the body weight of the mice was monitored over the course of the experiment. After 30 days, the tumors had grown to a final volume of $300-400 \mathrm{~mm}^{3}$.

BL Imaging of a Breast Cancer Model with BL $60^{-N O}$ - 4T1Luc tumor-bearing mice were treated with a sterile saline $(50$ $\mu \mathrm{L})$ or a $35 \mathrm{mM}$ solution of L-NMMA in sterile saline $(50 \mu \mathrm{L})$ via intratumoral injection. After one hour, BL $660-\mathrm{NO}$ was administered via retro-orbital injection. After an additional hour, the mice were imaged on the IVIS imaging system. Light was collected using the $660 \mathrm{~nm}$ filter set. An ROI was drawn around each tumor and the signal intensity was quantified using the Living Image Analysis Software. Results are reported as a ratio of tumor-bearing flank over non-tumor control flank.

Generation of Orthotopic 4T1-Luc Tumors and Diet Study. Female BALB/c mice (six to eight weeks old) were placed on a control diet (Research Diets No. D12450B,) or a high-fat diet (Research Diets No. D12452) where $10 \%$ or $60 \%$ of calories are from fat, respectively. After 12 weeks, mice were inoculated with $4 \mathrm{~T} 1$-Luc cells $\left(100 \mu \mathrm{L}\right.$ of $1 \times 10^{6}$ cells $/ \mathrm{mL}$ in $1: 1$ serumfree RPMI 1640 media and Matrigel) via subcutaneous injection into the mammary fat pad. Each group continued receiving their respective diets until the completion of the study. Their body weights were carefully monitored after inoculation. After 30 days, mice from both groups were treated with $\mathrm{BL}_{660^{-}}$ $\mathrm{NO}$, administered via retro-orbital injection, and imaged using the IVIS imaging system.

\section{ASSOCIATED CONTENT}

\section{Supporting Information}

The Supporting Information is available free of charge on the ACS Publications website at DOI: $\mathrm{xxx}$.

Further experimental details, including synthetic procedures, spectral data, and supplemental in vitro and in vivo procedures and data (PDF)

\section{AUTHOR INFORMATION}

\section{Corresponding Author}

*jeffchan@illinois.edu

ORCID

Anuj K. Yadav: 0000-0002-4736-4392

Michael C. Lee: 0000-0001-8125-7120

Melissa Y. Lucero: 0000-0002-7221-1144

Christopher J. Reinhardt: 0000-0001-9992-1253

Jefferson Chan: 0000-0003-4139-4379

\section{Present Addresses}

† Department of Chemistry, The Skaggs Institute for Chemical Biology, The Scripps Research Institute, La Jolla, California 92037, United State

\section{Author Contributions}

A.K.Y. synthesized BL $660-\mathrm{NO}$ and Ctrl-BL $660-\mathrm{NO}$, performed in vitro characterization, selectivity studies, and cellular imaging, and established a protocol for ratiometric calibration. M.C.L. generated the allograft breast cancer model and performed BL imaging with assistance from C.J.R. M.Y.L. generated the liver model and performed BL imaging with S.S. M.C.L. generated and performed BL imaging in the dietary-induced inflammation breast cancer model with M.Y.L. and S.S. M.Y.L. harvested and prepared tissue for immunohistostaining experiments with M.C.L. All authors analyzed and interpreted the data. A.K.Y. and J.C. wrote the manuscript. All authors have given approval to the final version of the manuscript.

\section{Funding Sources}

This work was supported the National Institutes of Health (R35GM133581).

\section{ACKNOWLEDGMENT}

M.C.L. thanks the National Science Foundation for a Graduate Fellowship. M.Y.L. acknowledges the Alfred P. Sloan Foundation for financial support. C.J.R. thanks the Chemistry-Biology Interface Training Grant (T32 GM070421) and the Seemon Pines Graduate Fellowship for support. Major funding for the $500 \mathrm{MHz}$ Bruker CryoProbe was provided by the Roy J. Carver Charitable Trust (Muscatine, Iowa; Grant No. 15-4521) to the School of Chemical Sciences NMR Lab. The Q-Tof Ultima mass spectrometer was purchased in part with a grant from the National Science Foundation, Division of Biological Infrastructure (DBI0100085). We also acknowledge Dr. Iwona Dobrucka and the Molecular Imaging Laboratory at the Beckman Institute for use of the IVIS imaging system. We thank Professor Benita Katzenellenbogen (Molecular and Integrative Physiology, UIUC) for providing 4T1-Luc mammary carcinoma cells. We also thank the Mr. Joseph Reid McClure of the Division of Animal Resources for administering the research diets and Drs. Nicole Herndon and Jessica $\mathrm{Xu}$ for helping to generate the heterotopic lung cancer model.

\section{ABBREVIATIONS}

DEA NONOate, Diethylammonium (Z)-1-(N,Ndiethylamino)diazen-1-ium-1,2-diolate; EPR, Electron paramagnetic resonance; L-NMMA, L-N ${ }^{\mathrm{G}}$-monomethyl Arginine acetate; LCMS, liquid chromatography mass spectrometry; MRI, Magnetic resonance imaging; PBS, phosphate buffer saline; ROI, region of interest; TLC, thin layer chromatography.

\section{REFERENCES}

(1) Zhao, Y.; Vanhoutte, P. M.; Leung, S. W. S. Vascular Nitric Oxide: Beyond ENOS. J. Pharmacol. Sci. 2015, 129 (2). https://doi.org/10.1016/j.jphs.2015.09.002.

(2) Yun, H.-Y.; Dawson, V. L.; Dawson, T. M. Nitric Oxide in Health and Disease of the Nervous System. Mol. Psychiatry 1997 2 (4). https://doi.org/10.1038/sj.mp.4000272.
Bogdan, C. Nitric Oxide and the Immune Response. Nat. Immunol. 2001, 2 (10). https://doi.org/10.1038/ni1001-907.

Shreshtha, S.; Sharma, P.; Kumar, P.; Sharma, R.; Singh, S. Nitric Oxide: It's Role in Immunity. J. Clin. DIAGNOSTIC Res. 2018. https://doi.org/10.7860/JCDR/2018/31817.11764.

Fukumura, D.; Kashiwagi, S.; Jain, R. K. The Role of Nitric Oxide in Tumour Progression. Nat. Rev. Cancer 2006, 6 (7). https://doi.org/10.1038/nrc1910.

Ridnour, L. A.; Thomas, D. D.; Switzer, C.; Flores-Santana, W.; Isenberg, J. S.; Ambs, S.; Roberts, D. D.; Wink, D. A. Molecular Mechanisms for Discrete Nitric Oxide Levels in Cancer. Nitric Oxide 2008, 19 (2). https://doi.org/10.1016/j.niox.2008.04.006. Lin, Y.; Xu, J.; Lan, H. Tumor-Associated Macrophages in Tumor Metastasis: Biological Roles and Clinical Therapeutic 
Applications. J. Hematol. Oncol. 2019, $12 \quad$ (1) https://doi.org/10.1186/s13045-019-0760-3.

Landskron, G.; De la Fuente, M.; Thuwajit, P.; Thuwajit, C.; Hermoso, M. A. Chronic Inflammation and Cytokines in the Tumor Microenvironment. J. Immunol. Res. 2014, 2014. https://doi.org/10.1155/2014/149185.

(9) Cranford, T. L.; Velázquez, K. T.; Enos, R. T.; Sougiannis, A. T.; Bader, J. E.; Carson, M. S.; Bellone, R. R.; Chatzistamou, I.; Nagarkatti, M.; Murphy, E. A. Effects of High Fat Diet-Induced Obesity on Mammary Tumorigenesis in the PyMT/MMTV Murine Model. Cancer Biol. Ther. 2019, 20 (4). https://doi.org/10.1080/15384047.2018.1537574

(10) Greenhill, C. High-Fat Diet and Dysbiosis Accelerate Tumorigenesis in Mice. Nat. Rev. Endocrinol. 2014, 10 (11). https://doi.org/10.1038/nrendo.2014.164.

(11) Rao, C. V.; Hirose, Y.; Indranie, C.; Reddy, B. S. Modulation of Experimental Colon Tumorigenesis by Types and Amounts of Dietary Fatty Acids. Cancer Res. 2001, 61 (5), 1927-1933.

(12) Duan, Y.; Zeng, L.; Zheng, C.; Song, B.; Li, F.; Kong, X.; Xu, K. Inflammatory Links Between High Fat Diets and Diseases. Front. Immunol. 2018, 9. https://doi.org/10.3389/fimmu.2018.02649.

(13) Bojková, B.; Winklewski, P. J.; Wszedybyl-Winklewska, M. Dietary Fat and Cancer-Which Is Good, Which Is Bad, and the Body of Evidence. Int. J. Mol. Sci. 2020, 21 (11). https://doi.org/10.3390/ijms21114114.

(14) Tsuchiya, K.; Takasugi, M.; Minakuchi, K.; Fukuzawa, K. Sensitive Quantitation of Nitric Oxide by EPR Spectroscopy. Free Radic. Biol. Med. 1996, $21 \quad$ (5) https://doi.org/10.1016/0891-5849(96)00221-3.

(15) Yoshimura, T.; Yokoyama, H.; Fujii, S.; Takayama, F.; Oikawa, K.; Kamada, H. In Vivo EPR Detection and Imaging of Endogenous Nitric Oxide in Lipopolysaccharide-Treated Mice. Nat. Biotechnol. 1996, 14 (8). https://doi.org/10.1038/nbt0896992.

(16) Barandov, A.; Ghosh, S.; Li, N.; Bartelle, B. B.; Daher, J. I.; Pegis, M. L.; Collins, H.; Jasanoff, A. Molecular Magnetic Resonance Imaging of Nitric Oxide in Biological Systems. ACS Sensors 2020, 5 (6). https://doi.org/10.1021/acssensors.0c00322.

(17) Sharma, R.; Seo, J.-W.; Kwon, S. In Vivo Imaging of Nitric Oxide by Magnetic Resonance Imaging Techniques. J. Nanomater. 2014, 2014. https://doi.org/10.1155/2014/523646.

(18) Yusoff, N.; Rameshkumar, P.; Shahid, M. M.; Huang, S.-T.; Huang, N. M. Amperometric Detection of Nitric Oxide Using a Glassy Carbon Electrode Modified with Gold Nanoparticles Incorporated into a Nanohybrid Composed of Reduced Graphene Oxide and Nafion. Microchim. Acta 2017, 184 (9). https://doi.org/10.1007/s00604-017-2344-7.

(19) Gardner, S. H.; Reinhardt, C. J.; Chan, J. Advances in ActivityBased Sensing Probes for Isoform-Selective Imaging of Enzymatic Activity. Angew. Chemie Int. Ed. 2020. https://doi.org/10.1002/anie.202003687.

(20) Yadav, A. K.; Reinhardt, C. J.; Arango, A. S.; Huff, H. C.; Dong, L.; Malkowski, M. G.; Das, A.; Tajkhorshid, E.; Chan, J. An Activity-Based Sensing Approach for the Detection of Cyclooxygenase-2 in Live Cells. Angew. Chemie Int. Ed. 2020 , 59 (8). https://doi.org/10.1002/anie.201914845.

(21) Gabe, Y.; Urano, Y.; Kikuchi, K.; Kojima, H.; Nagano, T. Highly Sensitive Fluorescence Probes for Nitric Oxide Based on Boron Dipyrromethene ChromophoreRational Design of Potentially Useful Bioimaging Fluorescence Probe. J. Am. Chem. Soc. 2004, 126 (10). https://doi.org/10.1021/ja037944j.

(22) Sasaki, E.; Kojima, H.; Nishimatsu, H.; Urano, Y.; Kikuchi, K.; Hirata, Y.; Nagano, T. Highly Sensitive Near-Infrared Fluorescent Probes for Nitric Oxide and Their Application to Isolated Organs. J. Am. Chem. Soc. 2005, 127 (11). https://doi.org/10.1021/ja042967z.

(23) Lim, M. H.; Xu, D.; Lippard, S. J. Visualization of Nitric Oxide in Living Cells by a Copper-Based Fluorescent Probe. Nat. Chem. Biol. 2006, 2 (7). https://doi.org/10.1038/nchembio794.

(24) Pluth, M. D.; McQuade, L. E.; Lippard, S. J. Cell-Trappable Fluorescent Probes for Nitric Oxide Visualization in Living Cells. Org. Lett. 2010, 12 (10). https://doi.org/10.1021/ol1006289.

(25) Chen, Y. Recent Developments of Fluorescent Probes for Detection and Bioimaging of Nitric Oxide. Nitric Oxide 2020, 98. https://doi.org/10.1016/j.niox.2020.02.002.
Mao, Z.; Jiang, H.; Li, Z.; Zhong, C.; Zhang, W.; Liu, Z. An NNitrosation Reactivity-Based Two-Photon Fluorescent Probe for the Specific in Situ Detection of Nitric Oxide. Chem. Sci. 2017, 8 (6). https://doi.org/10.1039/C7SC00416H.

Reinhardt, C. J.; Zhou, E. Y.; Jorgensen, M. D.; Partipilo, G.; Chan, J. A Ratiometric Acoustogenic Probe for in Vivo Imaging of Endogenous Nitric Oxide. J. Am. Chem. Soc. 2018, 140 (3), 1011-1018. https://doi.org/10.1021/jacs.7b10783.

Wang, S.; Li, Z.; Liu, Y.; Feng, G.; Zheng, J.; Yuan, Z.; Zhang, $X$. Activatable Photoacoustic and Fluorescent Probe of Nitric Oxide for Cellular and in Vivo Imaging. Sensors Actuators B Chem. 2018, 267. https://doi.org/10.1016/j.snb.2018.04.052.

Qi, J.; Feng, L.; Zhang, X.; Zhang, H.; Huang, L.; Zhou, Y.; Zhao, Z.; Duan, X.; Xu, F.; Kwok, R. T. K.; Lam, J. W. Y.; Ding, D.; Xue, X.; Tang, B. Z. Facilitation of Molecular Motion to Develop Turn-on Photoacoustic Bioprobe for Detecting Nitric Oxide in Encephalitis. Nat. Commun. 2021, 12 (1). https://doi.org/10.1038/s41467-021-21208-1.

Zhou, E. Y.; Knox, H. J.; Reinhardt, C. J.; Partipilo, G.; Nilges, M. J.; Chan, J. Near-Infrared Photoactivatable Nitric Oxide Donors with Integrated Photoacoustic Monitoring. J. Am. Chem. Soc. 2018, 140 (37). https://doi.org/10.1021/jacs.8b05514.

Zhou, E. Y.; Knox, H. J.; Liu, C.; Zhao, W.; Chan, J. A Conformationally Restricted Aza-BODIPY Platform for Stimulus-Responsive Probes with Enhanced Photoacoustic Properties. J. Am. Chem. Soc. 2019, 141 (44). https://doi.org/10.1021/jacs.9b06694.

Reinhardt, C. J.; Xu, R.; Chan, J. Nitric Oxide Imaging in Cancer Enabled by Steric Relaxation of a Photoacoustic Probe Platform. Chem. Sci. 2020, 11 (6). https://doi.org/10.1039/C9SC05600A.

Yadav, A. K.; Hernandez, S.; Su, S.; Chan, J. Acoustic-Based Chemical Tools for Profiling the Tumor Microenvironment. Curr. Opin. Chem. Biol. 2020, 57. https://doi.org/10.1016/j.cbpa.2020.06.008

East, A. K.; Lucero, M. Y.; Chan, J. New Directions of ActivityBased Sensing for in Vivo NIR Imaging. Chem. Sci. 2021 https://doi.org/10.1039/D0SC03096A.

Yao, Z.; Zhang, B. S.; Prescher, J. A. Advances in Bioluminescence Imaging: New Probes from Old Recipes. Curr. $\begin{array}{llll}\text { Opin. } & \text { Chem. } & \text { Biol. }\end{array}$ https://doi.org/10.1016/j.cbpa.2018.05.009.

Su, T. A.; Bruemmer, K. J.; Chang, C. J. Caged Luciferins for Bioluminescent Activity-Based Sensing. Curr. Opin. Biotechnol. 2019, 60. https://doi.org/10.1016/j.copbio.2019.05.002.

Zhou, W.; Shultz, J. W.; Murphy, N.; Hawkins, E. M.; Bernad, L.; Good, T.; Moothart, L.; Frackman, S.; Klaubert, D. H.; Bulleit, R. F.; Wood, K. V. Electrophilic Aromatic Substituted Luciferins as Bioluminescent Probes for Glutathione STransferase Assays. Chem. Commun. 2006, No. 44. https://doi.org/10.1039/b610682j.

Cohen, A. S.; Dubikovskaya, E. A.; Rush, J. S.; Bertozzi, C. R. Real-Time Bioluminescence Imaging of Glycans on Live Cells. J. Am. Chem. Soc. 2010, 132 (25). https://doi.org/10.1021/ja101766r.

Van de Bittner, G. C.; Bertozzi, C. R.; Chang, C. J. Strategy for Dual-Analyte Luciferin Imaging: In Vivo Bioluminescence Detection of Hydrogen Peroxide and Caspase Activity in a Murine Model of Acute Inflammation. J. Am. Chem. Soc. 2013, 135 (5). https://doi.org/10.1021/ja309078t.

Duellman, S. J.; Valley, M. P.; Kotraiah, V.; Vidugiriene, J.; Zhou, W.; Bernad, L.; Osterman, J.; Kimball, J. J.; Meisenheimer, P.; Cali, J. J. A Bioluminescence Assay for Aldehyde Dehydrogenase Activity. Anal. Biochem. 2013, 434 (2). https://doi.org/10.1016/j.ab.2012.11.016.

Shah, K.; Tung, C.-H.; Breakefield, X. O.; Weissleder, R. In Vivo Imaging of S-TRAIL-Mediated Tumor Regression and Apoptosis. Mol. Ther. 2005, $11 \quad$ (6). https://doi.org/10.1016/j.ymthe.2005.01.017.

Vorobyeva, A. G.; Stanton, M.; Godinat, A.; Lund, K. B.; Karateev, G. G.; Francis, K. P.; Allen, E.; Gelovani, J. G.; McCormack, E.; Tangney, M.; Dubikovskaya, E. A Development of a Bioluminescent Nitroreductase Probe for Preclinical Imaging. PLoS One 2015, 10 (6). https://doi.org/10.1371/journal.pone.0131037.

Yao, H.; So, M.; Rao, J. A Bioluminogenic Substrate for In Vivo 
Imaging of $\beta$-Lactamase Activity. Angew. Chemie Int. Ed. 2007 46 (37). https://doi.org/10.1002/anie.200701931.

(44) Juttukonda, L. J.; Green, E. R.; Lonergan, Z. R.; Heffern, M. C; Chang, C. J.; Skaar, E. P. Acinetobacter Baumannii OxyR Regulates the Transcriptional Response to Hydrogen Peroxide. Infect. Immun. 2018, 87 (1). https://doi.org/10.1128/IAI.0041318.

(45) Heffern, M. C.; Park, H. M.; Au-Yeung, H. Y.; Van de Bittner, G. C.; Ackerman, C. M.; Stahl, A.; Chang, C. J. In Vivo Bioluminescence Imaging Reveals Copper Deficiency in a Murine Model of Nonalcoholic Fatty Liver Disease. Proc. Natl. Acad. Sci. 2016, 113 https://doi.org/10.1073/pnas.1613628113.

(46) Aron, A. T.; Heffern, M. C.; Lonergan, Z. R.; Vander Wal, M. N.; Blank, B. R.; Spangler, B.; Zhang, Y.; Park, H. M.; Stahl, A.; Renslo, A. R.; Skaar, E. P.; Chang, C. J. In Vivo Bioluminescence Imaging of Labile Iron Accumulation in a Murine Model of Acinetobacter Baumannii Infection. Proc. Natl. Acad. Sci. 2017, 114 (48). https://doi.org/10.1073/pnas.1708747114.

(47) Mofford, D. M.; Adams, S. T.; Reddy, G. S. K. K.; Reddy, G. R.; Miller, S. C. Luciferin Amides Enable in Vivo Bioluminescence Detection of Endogenous Fatty Acid Amide Hydrolase Activity. J. Am. Chem. Soc. 2015, $137 \quad$ (27) https://doi.org/10.1021/jacs.5b04357.

(48) Takakura, H.; Kojima, R.; Kamiya, M.; Kobayashi, E.; Komatsu, T.; Ueno, T.; Terai, T.; Hanaoka, K.; Nagano, T.; Urano, Y. New Class of Bioluminogenic Probe Based on Bioluminescent Enzyme-Induced Electron Transfer: BioLeT. J. Am. Chem. Soc. 2015, 137 (12). https://doi.org/10.1021/ja511014w.

(49) Iwano, S.; Obata, R.; Miura, C.; Kiyama, M.; Hama, K.; Nakamura, M.; Amano, Y.; Kojima, S.; Hirano, T.; Maki, S.; Niwa, H. Development of Simple Firefly Luciferin Analogs Emitting Blue, Green, Red, and near-Infrared Biological Window Light. Tetrahedron 2013, 69 (19) https://doi.org/10.1016/j.tet.2013.03.050.

(50) Kuchimaru, T.; Iwano, S.; Kiyama, M.; Mitsumata, S.; Kadonosono, T.; Niwa, H.; Maki, S.; Kizaka-Kondoh, S. A Luciferin Analogue Generating Near-Infrared Bioluminescence Achieves Highly Sensitive Deep-Tissue Imaging. Nat. Commun. 2016, 7 (1). https://doi.org/10.1038/ncomms 11856

(51) Reddy, G. R.; Thompson, W. C.; Miller, S. C. Robust Light Emission from Cyclic Alkylaminoluciferin Substrates for Firefly Luciferase. J. Am. Chem. Soc. 2010, 132 (39). https://doi.org/10.1021/ja104525m.

(52) Jathoul, A. P.; Grounds, H.; Anderson, J. C.; Pule, M. A. A DualColor Far-Red to Near-Infrared Firefly Luciferin Analogue Designed for Multiparametric Bioluminescence Imaging. Angew. Chemie Int. Ed. 2014, 53 (48) https://doi.org/10.1002/anie.201405955.

(53) Iwano, S.; Sugiyama, M.; Hama, H.; Watakabe, A.; Hasegawa N.; Kuchimaru, T.; Tanaka, K. Z.; Takahashi, M.; Ishida, Y.; Hata, J.; Shimozono, S.; Namiki, K.; Fukano, T.; Kiyama, M.; Okano, H.; Kizaka-Kondoh, S.; McHugh, T. J.; Yamamori, T.; Hioki, H.; Maki, S.; Miyawaki, A. Single-Cell Bioluminescence Imaging of Deep Tissue in Freely Moving Animals. Science (80). 2018, 359 (6378). https://doi.org/10.1126/science.aaq1067.

(54) Hall, M. P.; Woodroofe, C. C.; Wood, M. G.; Que, I.; van't Root, M.; Ridwan, Y.; Shi, C.; Kirkland, T. A.; Encell, L. P.; Wood, K. V.; Löwik, C.; Mezzanotte, L. Click Beetle Luciferase Mutant and near Infrared Naphthyl-Luciferins for Improved Bioluminescence Imaging. Nat. Commun. 2018, 9 (1). https://doi.org/10.1038/s41467-017-02542-9.

(55) Zambito, G.; Hall, M. P.; Wood, M. G.; Gaspar, N.; Ridwan, Y.; Stellari, F. F.; Shi, C.; Kirkland, T. A.; Encell, L. P.; Löwik, C.; Mezzanotte, L. Red-Shifted Click Beetle Luciferase Mutant Expands the Multicolor Bioluminescent Palette for Deep Tissue Imaging. $\quad$ 2021, 24 (1) https://doi.org/10.1016/j.isci.2020.101986.

(56) Knox, H. J.; Kim, T. W.; Zhu, Z.; Chan, J. Photophysical Tuning of $N$-Oxide-Based Probes Enables Ratiometric Photoacoustic Imaging of Tumor Hypoxia. ACS Chem. Biol. 2018, 13 (7). https://doi.org/10.1021/acschembio.8b00099.

(57) Zheng, H.; Shang, G.-Q.; Yang, S.-Y.; Gao, X.; Xu, J.-G. Fluorogenic and Chromogenic Rhodamine Spirolactam Based Probe for Nitric Oxide by Spiro Ring Opening Reaction. Org.
Lett. 2008, 10 (12). https://doi.org/10.1021/ol800206x.

Ikeda, Y.; Nomoto, T.; Hiruta, Y.; Nishiyama, N.; Citterio, D. Ring-Fused Firefly Luciferins: Expanded Palette of Near-Infrared Emitting Bioluminescent Substrates. Anal. Chem. 2020, 92 (6). https://doi.org/10.1021/acs.analchem.9b04562.

Xu, Y.; Shi, D.; Wang, X.; Yu, S.; Yu, X.; Pu, L. Development of Aldehyde-Based Fluorescent Probes for Highly Selective Recognition of 1,3-Diaminopropane. European J. Org. Chem. 2017, 2017 (33). https://doi.org/10.1002/ejoc.201700962.

Dilek, O.; Bane, S. Turn on Fluorescent Probes for Selective Targeting of Aldehydes. Chemosensors 2016, 4 (1). https://doi.org/10.3390/chemosensors4010005.

Fu, Y.; Gao, Y.; Chen, L.; He, Q.; Zhu, D.; Cao, H.; Cheng, J. Highly Efficient Single Fluorescent Probe for Multiple Amine Vapours via Reaction between Amine and Aldehyde/Dioxaborolane. $R S C \quad A d v$. 2014, $4 \quad$ (87). https://doi.org/10.1039/C4RA08995B.

Wong, V. (Wai C.; Lerner, E. Nitric Oxide Inhibition Strategies. Futur. Sci. OA 2015, 1 (1). https://doi.org/10.4155/fso.15.35. Le Guennec, D.; Hatte, V.; Farges, M.-C.; Rougé, S.; Goepp, M.; Caldefie-Chezet, F.; Vasson, M.-P.; Rossary, A. Modulation of Inter-Organ Signalling in Obese Mice by Spontaneous Physical Activity during Mammary Cancer Development. Sci. Rep. 2020, 10 (1). https://doi.org/10.1038/s41598-020-65131-9.

Hermano, E.; Goldberg, R.; Rubinstein, A. M.; Sonnenblick, A.; Maly, B.; Nahmias, D.; Li, J.-P.; Bakker, M. A. H.; van der Vlag, J.; Vlodavsky, I.; Peretz, T.; Elkin, M. Heparanase Accelerates Obesity-Associated Breast Cancer Progression. Cancer Res. 2019, 79 (20). https://doi.org/10.1158/0008-5472.CAN-18-4058. Soldati, L.; Di Renzo, L.; Jirillo, E.; Ascierto, P. A.; Marincola, F. M.; De Lorenzo, A. The Influence of Diet on Anti-Cancer Immune Responsiveness. J. Transl. Med. 2018, 16 (1). https://doi.org/10.1186/s12967-018-1448-0.

Kado, T.; Nawaz, A.; Takikawa, A.; Usui, I.; Tobe, K. Linkage of CD8+ $\mathrm{T}$ Cell Exhaustion with High-Fat Diet-Induced Tumourigenesis. Sci. Rep. 2019, 9 (1). https://doi.org/10.1038/s41598-019-48678-0.

Wang, K.; Sun, J.-Z.; Wu, Q.-X.; Li, Z.-Y.; Li, D.-X.; Xiong, Y.F.; Zhong, G.-C.; Shi, Y.; Li, Q.; Zheng, J.; Shivappa, N.; Hébert, J. R.; Foukakis, T.; Zhang, X.; Li, H.-Y.; Xiang, T.-X.; Ren, G.S. Long-Term Anti-Inflammatory Diet in Relation to Improved Breast Cancer Prognosis: A Prospective Cohort Study. npj Breast Cancer 2020, 6 (1). https://doi.org/10.1038/s41523-020-00179-4. Hayashi, T.; Fujita, K.; Nojima, S.; Hayashi, Y.; Nakano, K.; Ishizuya, Y.; Wang, C.; Yamamoto, Y.; Kinouchi, T.; Matsuzaki, K.; Jingushi, K.; Kato, T.; Kawashima, A.; Nagahara, A.; Ujike, T.; Uemura, M.; Pena, M. D. C. R.; Gordetsky, J. B.; Morii, E.; Tsujikawa, K.; Netto, G. J.; Nonomura, N. High-Fat Diet-Induced Inflammation Accelerates Prostate Cancer Growth via IL6 Signaling. Clin. Cancer Res. 2018, 24 (17). https://doi.org/10.1158/1078-0432.CCR-18-0106.

Sieri, S.; Chiodini, P.; Agnoli, C.; Pala, V.; Berrino, F.; Trichopoulou, A.; Benetou, V.; Vasilopoulou, E.; Sánchez, M.-J.; Chirlaque, M.-D.; Amiano, P.; Quirós, J. R.; Ardanaz, E.; Buckland, G.; Masala, G.; Panico, S.; Grioni, S.; Sacerdote, C.; Tumino, R.; Boutron-Ruault, M.-C.; Clavel-Chapelon, F.; Fagherazzi, G.; Peeters, P. H. M.; van Gils, C. H.; Bueno-deMesquita, H. B.; van Kranen, H. J.; Key, T. J.; Travis, R. C.; Khaw, K. T.; Wareham, N. J.; Kaaks, R.; Lukanova, A.; Boeing, H.; Schütze, M.; Sonestedt, E.; Wirfält, E.; Sund, M.; Andersson, A.; Chajes, V.; Rinaldi, S.; Romieu, I.; Weiderpass, E.; Skeie, G.; Dagrun, E.; Tjønneland, A.; Halkjær, J.; Overvard, K.; Merritt, M. A.; Cox, D.; Riboli, E.; Krogh, V. Dietary Fat Intake and Development of Specific Breast Cancer Subtypes. JNCI J. Natl. Cancer Inst. 2014, 106 (5). https://doi.org/10.1093/jnci/dju068. Sadikot, R. T. Bioluminescence Imaging. Proc. Am. Thorac. Soc. 2005, 2 (6). https://doi.org/10.1513/pats.200507-067DS. Larionova, I.; Tuguzbaeva, G.; Ponomaryova, A.; Stakheyeva, M.; Cherdyntseva, N.; Pavlov, V.; Choinzonov, E.; Kzhyshkowska, J. Tumor-Associated Macrophages in Human Breast, Colorectal, Lung, Ovarian and Prostate Cancers. Front. Oncol. 2020, 10. https://doi.org/10.3389/fonc.2020.566511.

Cassetta, L.; Fragkogianni, S.; Sims, A. H.; Swierczak, A.; Forrester, L. M.; Zhang, H.; Soong, D. Y. H.; Cotechini, T.; Anur, P.; Lin, E. Y.; Fidanza, A.; Lopez-Yrigoyen, M.; Millar, M. R.; 
Urman, A.; Ai, Z.; Spellman, P. T.; Hwang, E. S.; Dixon, J. M.; Wiechmann, L.; Coussens, L. M.; Smith, H. O.; Pollard, J. W. Human Tumor-Associated Macrophage and Monocyte Transcriptional Landscapes Reveal Cancer-Specific
Reprogramming, Biomarkers, and Therapeutic Targets. Cancer Cell 2019, 35 (4). https://doi.org/10.1016/j.ccell.2019.02.009. 
TOC Figure:
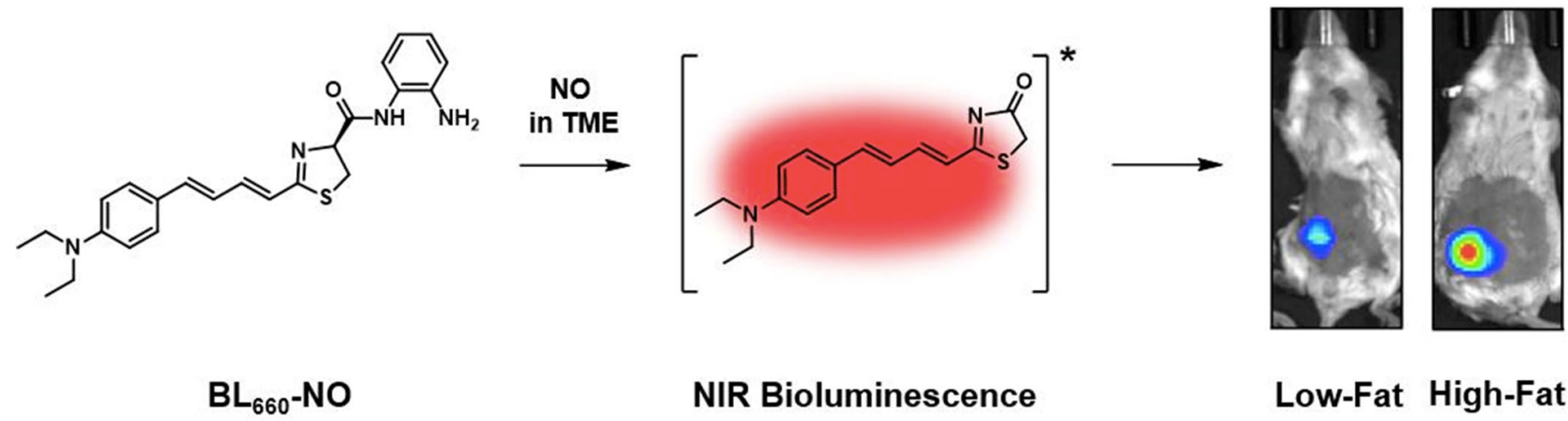

$\mathrm{BL}_{660}-\mathrm{NO}$

NIR Bioluminescence

Low-Fat High-Fat 